\title{
3. PERIDOTITES DRILLED FROM THE TYRRHENIAN SEA, ODP LEG $107^{1}$
}

\author{
E. Bonatti, ${ }^{2}$ M. Seyler, ${ }^{2}$ J. Channell, ${ }^{3}$ J. Giraudeau, ${ }^{4}$ and G. Mascle ${ }^{5}$
}

\begin{abstract}
Hole 651A, drilled during ODP leg 107 in the Tyrrhenian Sea, bottomed in a 30-m-thick section of serpentinized peridotite. Site 651 was drilled on the eastern flank of a north-south trending basement high located along the axis of the Vavilov basin. Peridotite is overlain by a 136-m-thick basement section consisting of two distinct basalt units separated by a dolerite-albitite intrusive unit. Peridotite has a tectonitic texture and probably derived from the upper mantle; it was affected by a complex history of ductile and brittle deformation. High temperature $\left(>700^{\circ} \mathrm{C}\right)$ hydrous metasomatism, which probably occurred at upper mantle levels and produced tschermakitic and $\mathrm{Mg}$-hornblende, tremolite, and possibly chlorite, affected the peridotite. Lower temperature metamorphic events followed, which gave rise to talcquartz \pm chlorite assemblages and to serpentinization. A relict primary assemblage consists of olivine, variable amounts of orthopyroxene, and spinel, implying that the rocks were originally harzburgite and dunite. Both bulk rock and relict primary mineral chemistry suggest that the peridotite is highly depleted, and chemically distinct from mantlederived peridotites from circum-Tyrrhenian ophiolites (North Apennine, Corsica), from passive margins and from the ocean basins. ODP Site 651 peridotite appears to have affinity with modern (Mariana, Tonga, and Puerto Rico Trenches) and ophiolitic (Troodos, Vourinos) arc-subduction related peridotites. It may represent a refractory upper mantle sliver which was affected by island arc/subduction systems inferred to have migrated southeast from Sardinia during the opening of the Tyrrhenian Sea.
\end{abstract}

\section{INTRODUCTION}

The Tyrrhenian Sea is a complex basin which has been interpreted both as a passive margin in the making, and as a backarc basin related to an inferred subduction zone dipping northwest beneath southern Italy and Sicily (Fig. 1). Two deep basins, the Vavilov and Marsili basins, located in the central and southern parts of the Tyrrhenian (Fig. 1), are floored by a relatively thin crust (Steinmetz et al., 1983) and are the locus of relatively high (up to $200 \mathrm{~m} \mathrm{~W} / \mathrm{m}^{2}$ ) heat flow (Della Vedova et al., 1984). Drilling of the northernmost Vavilov basin was carried out during ODP Leg 107 at two sites (Site 651 and Site 655). Whereas only basalt flows for a thickness of $120 \mathrm{~m}$ were encountered in the basement of Site 655 , serpentinized peridotite was penetrated at Site 651 for $30 \mathrm{~m}$ beneath $136 \mathrm{~m}$ of a prevalently basaltic section.

This paper presents preliminary results of a petrologic and structural study of ODP Site 651 peridotites. The objectives of this study are to first establish if the peridotites were originally upper mantle material, or if they were lower crustal cumulates. If they were derived from the upper mantle, as suggested by preliminary observations made during the drilling cruise (Shipboard Scientific Party, 1987b) these rocks can provide information on the nature of the upper mantle beneath the central Tyrrhenian, and they can help us to determine: (1) whether the peridotites are equivalent to Mesozoic Alpine and Apennine ophiolitic ultramafics, or whether they are younger fragments of mantle emplaced at shallow crustal levels during rifting in the Tyrrhenian Sea; (2) whether or not the mantle represented by these peridotites has been affected by the subduction system which presumably migrated through the southern Tyrrhenian; and (3) by what mechanism the upper mantle or lower crustal

\footnotetext{
${ }^{1}$ Kastens, K. A., Mascle, J., et al., 1990. Proc. ODP, Sci. Results, 107: College Station, TX (Ocean Drilling Program).

${ }^{2}$ Lamont-Doherty Geological Observatory of Columbia University, Palisades, NY 10964.

${ }^{3}$ University of Florida, Gainesville, FL.

${ }^{4}$ Université de Paris 7, France.

5 Université de Grenoble, France.
}

peridotite body has been emplaced at shallow crustal levels beneath the Tyrrhenian Sea floor.

\section{Stratigraphic Position of Site 651 Peridotites}

Site 651 was drilled on the eastern flank of a north-south trending basement swell along the axis of the Vavilov basin, to the north-northeast of the Vavilov seamount (Fig. 2). The basement swell divides the Vavilov basin in two sub-basins which are filled with as much as $800-900 \mathrm{~m}$ of layered sediments.

The sedimentary section at Site 651 is $388 \mathrm{~m}$ thick and PlioPleistocene in age. The Pleistocene section consists mainly of volcaniclastic components, which give way to mostly calcareous sediments in the Pliocene. Sapropel levels are found throughout the section. The lowermost $40 \mathrm{~m}$ above basement consist of a metal-enriched dolomitic sediment.

These basal dolomite-rich deposits do not contain fossils. The oldest datable sediments in the 651 section are in the unit immediately above the dolomitic sediment, i.e., $38 \mathrm{~m}$ above the sediment/basalt contact. They are Pliocene in age $(\sim 2.0$ m.y.b.p., biozone MPl6/NN18) (Shipboard Scientific Party, 1987b). Extrapolation based on the sedimentation rate of the $<2-\mathrm{m}$.y. section gives an age for the sediment/basement contact of about $3.6 \mathrm{~m}$.y. However, significant variations in sedimentation rate make this extrapolation uncertain, though lower Pliocene foraminifera found in cracks within the basalt give an age compatible with that obtained by the extrapolation (Shipboard Scientific Party, 1987b).

The basement drilled at Site 651 consists of the following units (Fig. 3).

Unit 1, 387.6-464 mbsf. Basalt crisscrossed by carbonate veins which decrease in abundance downhole. Several flows are recognized by the presence of chilled glass margins. Petrology and geochemistry suggest that Unit 1 basalt is intermediate in composition between MORB and high-K calc-alkaline magmas (Beccaluva et al., this volume).

Unit 2, Dolerite and albitite intrusives, 464-492 mbsf. This unit consists of a complex range of Ca-plagioclase-olivine dolerites, intercalations of Na-plagioclase + actinolite metadolerite and leucocratic coarse-grained albitites. Some fragments of me- 


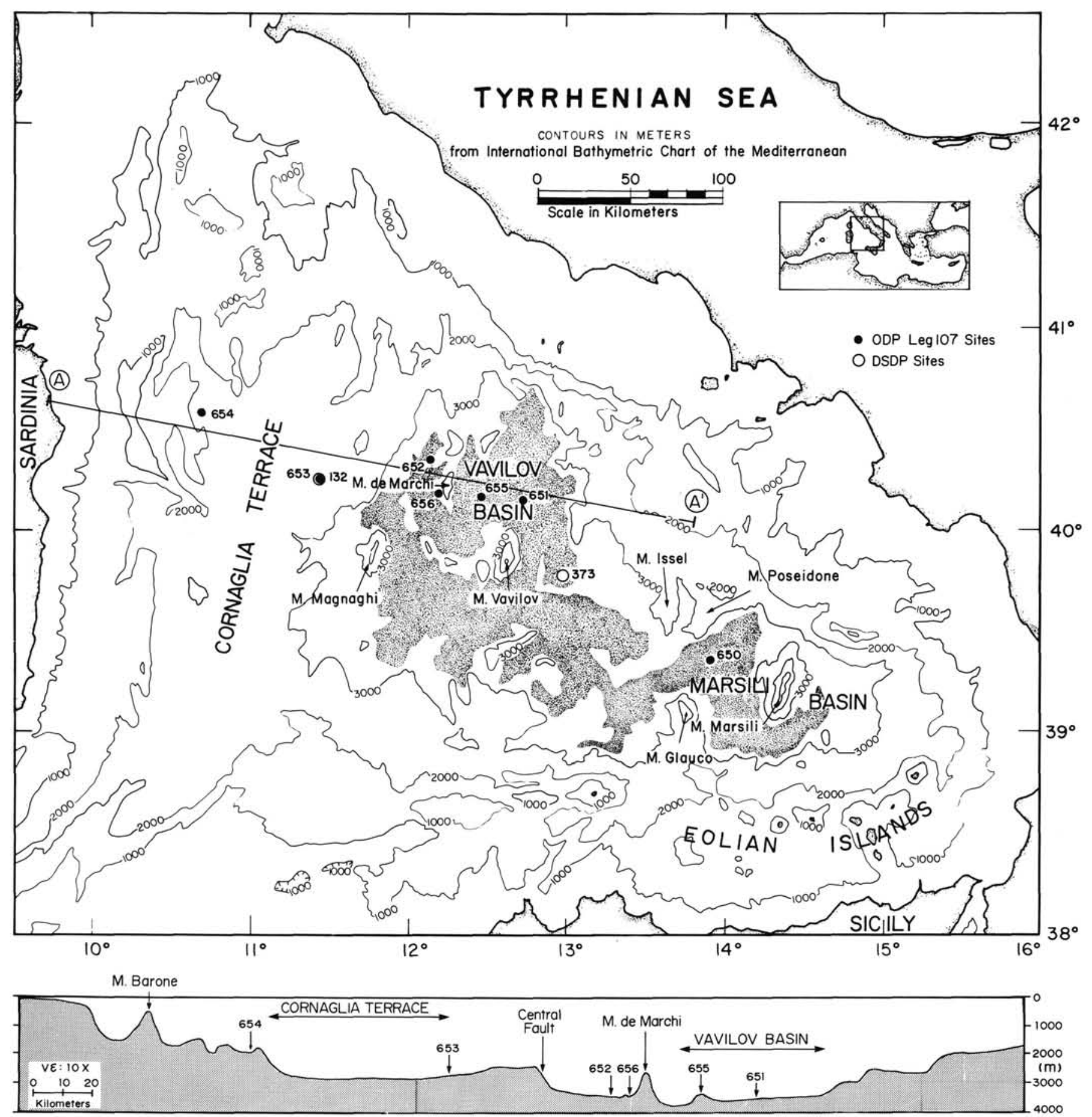

Figure 1. The Tyrrhenian Sea (from Kastens, Mascle, et al., 1988). Shadowed area indicates area deeper than $3400 \mathrm{~m}$ and shows the location of the Vavilov and Marsili basins with location of Site 651 and the other ODP sites drilled during leg 107. DSDP sites are also shown. The lower part of the figure shows a north-northwest/south-southeast profile of bathymetry and crustal thickness, the latter modified from Steinmetz et al. (1983).

taserpentinites were found near the top of this unit, which probably represents a sill or dike where extensive differentiation of the basaltic magma has taken place.

Unit 3, Lower basalt, $492-522$ mbsf. Basalt and carbonatecemented basaltic breccias make up this unit. This basalt appears distinct from that of Unit 1 , and has a more marked calcalkaline affinity (Beccaluva et al., this volume).

Unit 4, Serpentinized peridotite, 522-551 mbsf. This unit, which extends down to the bottom of the drilled section, consists entirely of serpentinized ultramafic rocks, except for two small ( $\sim 5 \mathrm{~cm}$ in diameter) fragments of a sheared, coarse grained quartz-feldspar biotite granitic rock found within the ultramafic section (Fig. 3). Thus, peridotites are overlain at Site 651 by a section roughly $136 \mathrm{~m}$ thick made essentially of basaltic rocks.

\section{METHODS}

Electron microprobe analyses were carried out at L-DGO with a four-spectrometer, fully automated Camebax unit, using natural standards and employing the Bence-Albee ZAF program for data correc- 


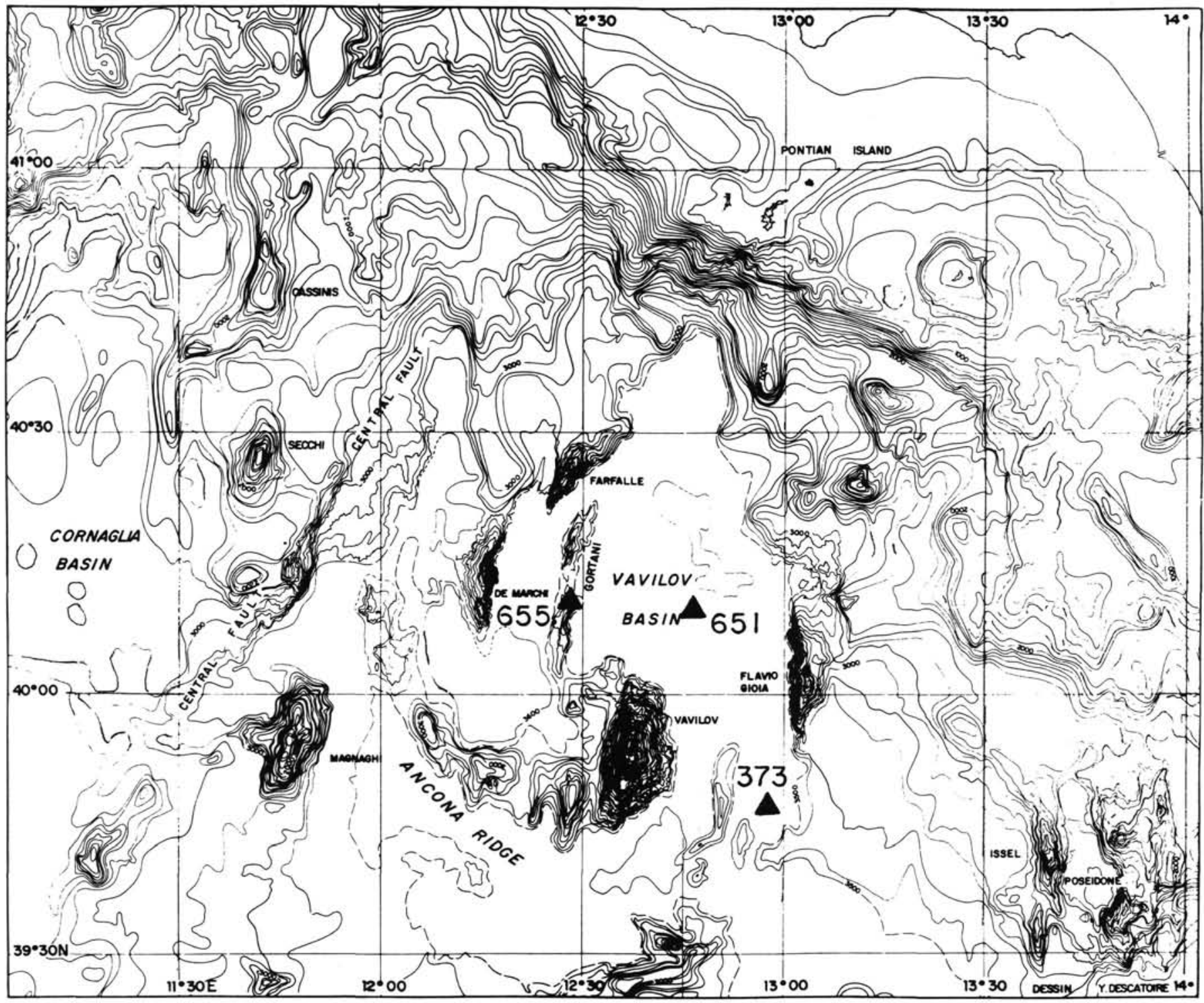

Figure 2. ODP Sites 651 and 655 and DSDP Site 373 in the Vavilov basin. Bathymetry is from Rehault et al. (1987).

tion. Major element composition was determined by a combination of $\mathrm{x}$-ray fluorescence and atomic absorption spectrometry. X-ray fluorescence analyses were performed on powder pellets with an automated Phillips PW 1450 unit. A matrix correction procedure by Franzini et al. (1975) was employed. $\mathrm{Ca}, \mathrm{Mg}, \mathrm{Na}$, and $\mathrm{K}$ were determined by atomic absorption using a Perkin Elmer 303 unit. $\mathrm{Fe}_{2} \mathrm{O}_{3} / \mathrm{FeO}$ was determined by colorimetric titration. X-ray diffraction analyses were carried out on powdered samples with a Phillips diffractometer, using $\mathrm{Ni}$-filtered $\mathrm{Cu}$ $\mathrm{K} \alpha$ radiation.

\section{STRUCTURE AND TEXTURE}

The ultramafic rocks cored at Site 651 are strongly serpentinized throughout. The cut sections have generally a pale to dark green "snake skin" appearance, with "islands" of large (up to $\sim 0.5 \mathrm{~cm}$ ) relict orthopyroxene crystals mostly altered to bastite. In some levels of the cores the rock is fine grained, black/green, and orthopyroxene crystals are not visible. The rock is intersected by a network of white veins ranging in width from about $1 \mathrm{~cm}$ to a fraction of a millimeter, made mostly of chrysotile. The rock displays sets of foliations which are marked by preferred orientation of chrysotile veins, of strained orthopyroxene, amphibole, and chlorite crystals, and of trains of spinel grains. The rock cores were sectioned whenever possible perpendicular to the observable foliation in order to facilitate the orientation of the structural elements.

A high-temperature foliation is marked by preferred-orientation and stretching of spinel and orthopyroxene crystals. The dip of this foliation is about $30^{\circ}$ in the serpentinized metaperidotites from the top of Core $50-1$, and about $45^{\circ}$ in those from Core 51-1 (Figs. 4, 5). Two generations of tensional fractures are present in this latter interval, the older dipping about $60^{\circ}$, the younger between $10^{\circ}$ and $20^{\circ}$. The thick peridotite unit at the bottom of the hole (Cores 56-1, 57-1, and 58-1 (Figs. 4, 5)) show a high-temperature foliation with dip ranging from $11^{\circ}$ to $62^{\circ}$. The dip averages $20^{\circ}$ in the upper part (Cores 56-1 and 571 ), and $35^{\circ}$ in the lower part (Cores 58-1) of the unit (Figs. 4, 5).

A lower temperature foliation was identified at some levels where chlorite is present (for instance, Core 58-1, 131-133 cm). This low-temperature foliation dips parallel to the high-temperature foliation determined from spinel and orthopyroxene crystals.

The direction of mineral lineation has been measured on cores and on nine oriented thin sections (Fig. 5). The angle be- 

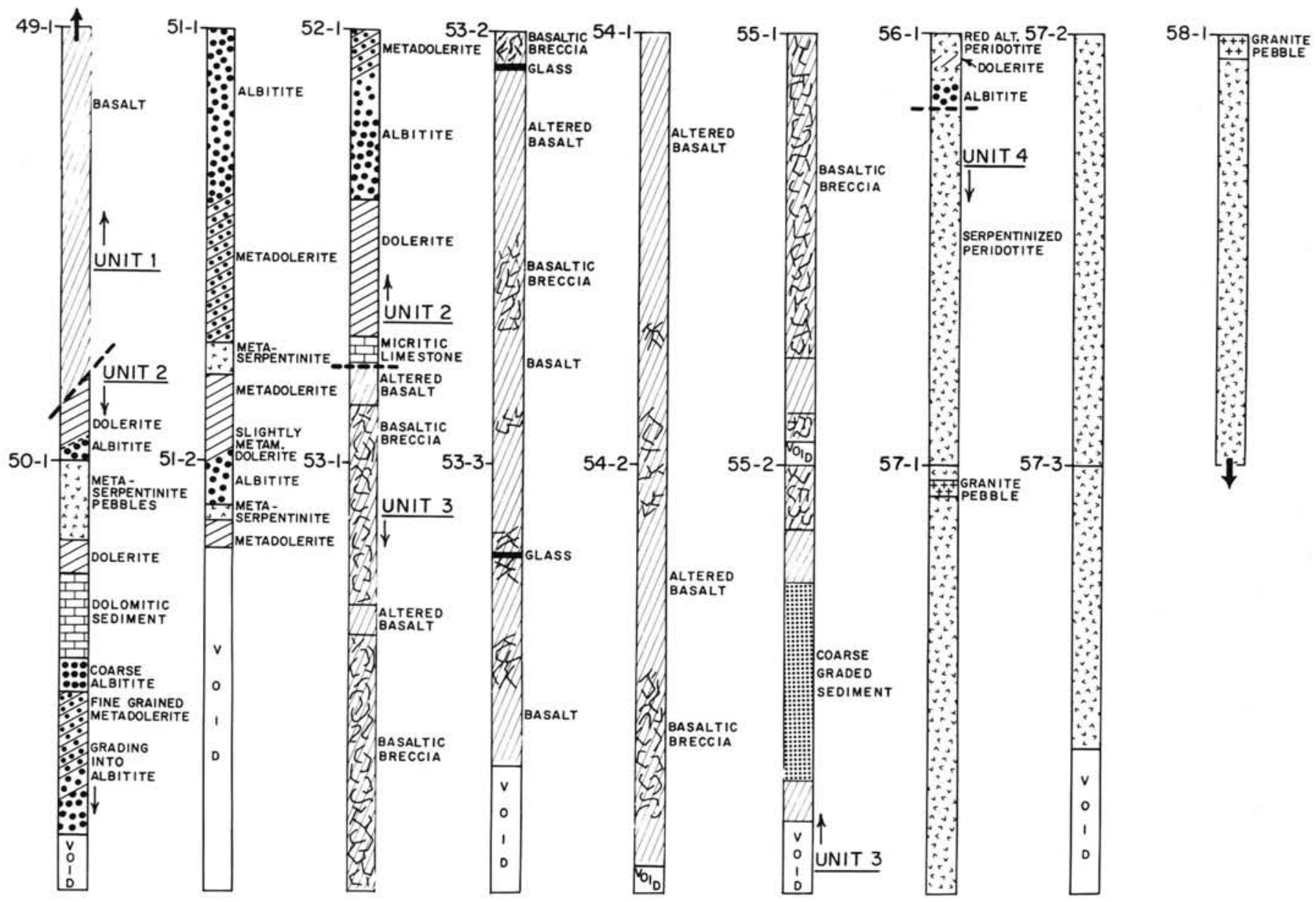

Figure 3. Simplified stratigraphy of part of the basement section drilled at Site 651 .

tween the direction of downdip foliation and the lineation shows a wide range, i.e., $3^{\circ}-90^{\circ}$, suggesting that the deformation which affected these rocks was characterized by an important strike slip component.

Three successive generations of open (tensional) microfractures have been observed. The oldest (F1) are common (Fig. 5) and their dip ranges from $10^{\circ}$ to vertical. Slickensides with $75^{\circ}$ pitch were observed, for instance, in Core $58-1$, at $4 \mathrm{~cm}, 18 \mathrm{~cm}$, and $44 \mathrm{~cm}$ depth. Conjugate patterns were also observed, for instance in Core $58-1,4 \mathrm{~cm}$ and $145 \mathrm{~cm}$ depth. All this suggests that the deformation was mainly tensional with a strike-slip component. F2 fractures are less common (Fig. 5); they dip from $30^{\circ}$ to vertical; slickensides are steeply dipping, with a pitch of $80^{\circ}$. F3 fractures are very common (Fig. 5); their dip ranges from close to horizontal to vertical. Often F3 fractures appear to have reutilized and reopened F1 fractures, as shown by the existence of successive infillings. These observations suggest that the stress field did not vary appreciably during the entire history of brittle deformation of these rocks, even though temperatures might have been decreasing.

We attempted to determine the absolute orientation of the structural elements in the lower part of the peridotite unit, (i.e., below 531.80 mbsf (Cores 57-1, -2, -3 and 58-1)) where we appear to have drilled a single coherent peridotite body. We used the foliation plane as references and we attempted to orient this plane using paleomagnetic data, following methods similar to those used by Shipboard Scientific Party (1987a) during ODP Leg 103. Twenty-three small core samples were drilled at various levels in Cores 57-1 and 58-1. The remnant magnetizations of these samples were measured using the shipboard fluxgate magnetometer (Table 1). Progressive alternating field demagnetization indicated that most of the samples were characterized by a low coercivity magnetization component with steep inclination. This component was probably acquired in the drill-string. Several samples from Core 57 yielded a very stable, higher coercivity component, resolved by alternating field demagnetization, with inclination close to that expected for a recent or Plio-Pleistocene geomagnetic field at the sampling site $\left(\sim 60^{\circ}\right)$, and consistent declination within unbroken core sections (Table 1). Assuming that this component was acquired prior to drilling (in a recent or Plio-Pleistocene geomagnetic field), we can reconstruct the approximate azimuthal orientation of the core by assigning a north direction to the component declination. After reconstruction of the core orientation, the strike of the foliation plane becomes oriented fairly consistently in a northwest-southeast direction, and the lineation close to north-northwest/southsoutheast.

\section{PETROGRAPHY AND MINERAL CHEMISTRY}

Observation under the microscope shows that the samples are highly serpentinized, with relicts of spinel, olivine, amphibole, and opx. Opx ghosts are relatively abundant in some levels, but scarce or absent in other levels, suggesting that the original rocks ranged from opx-rich harzburgite to dunite. A foliation is visible, defined by trains of spinel crystals and by isoorientation of amphiboles. Amphiboles are found as clusters or as isolated crystals, generally strained. In some samples patches and veinlets are filled with a metamorphic assemblage contain- 


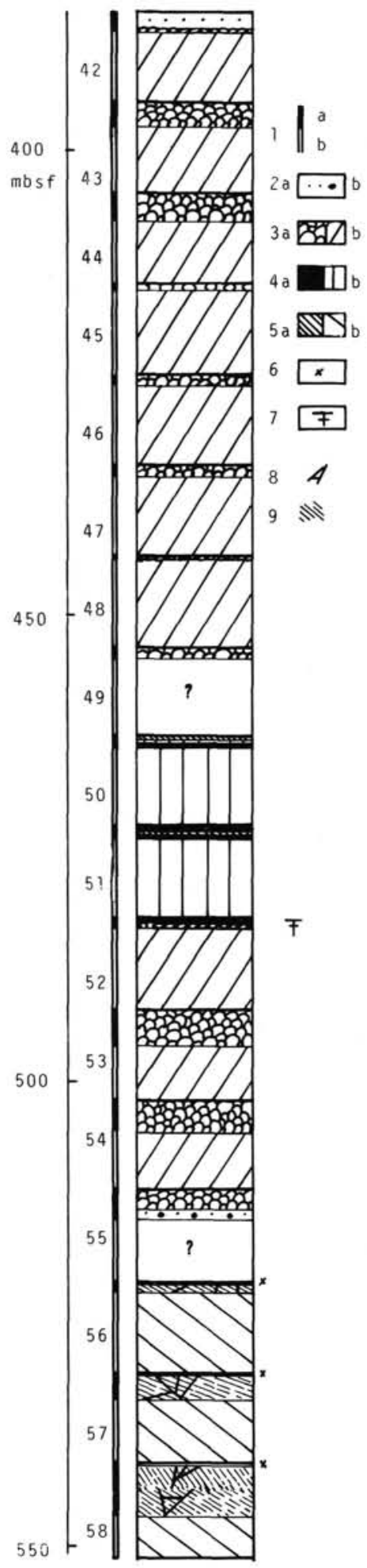

Figure 4. Schematic section of basement at Hole 651A with some information on structures. 1 = number of core ( $a$, recovered; $b$, cored); 2 = sediments (a, dolomitic ooze; b, serpentine breccia); $3=$ basalts ( $a$, cored; b, inferred); $4=$ dolerites and associated albitites (a, cored; $b$, inferred; $5=$ peridotites ( $a$, cored; $b$, inferred); $6=$ occurrence of granitoid pebbles; $7=$ microfossils (Globorotalia crassaformis); $8=$ tensional faults; 9 = dip of foliation in the peridotites.

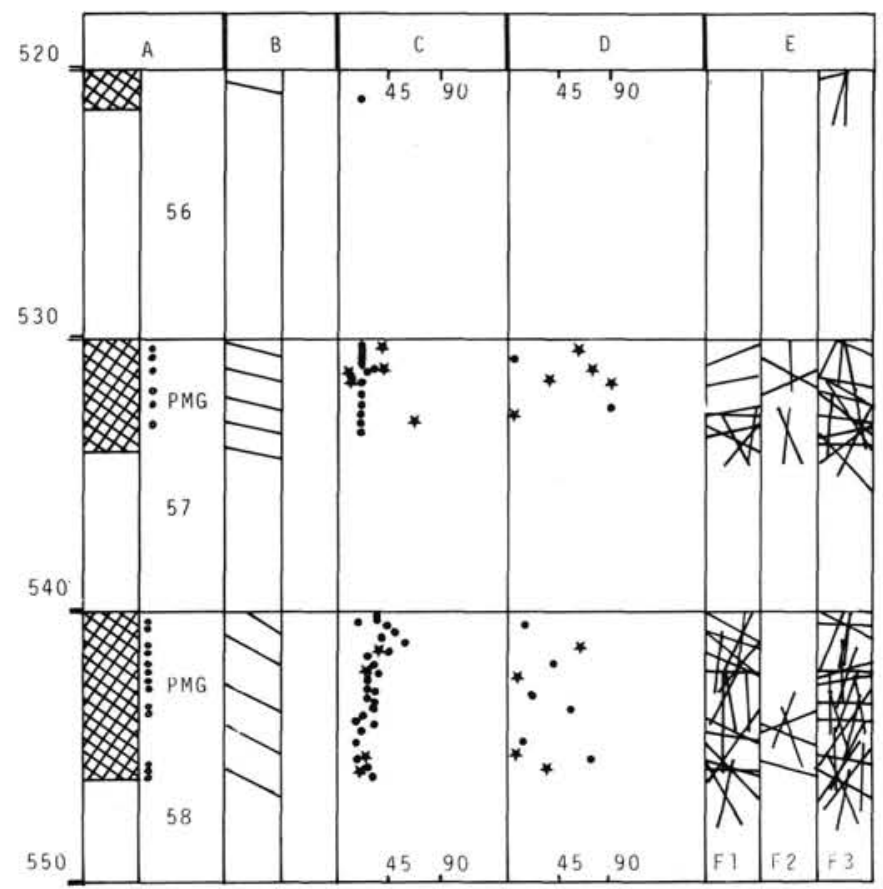

Figure 5. Schematic structural and microstructural cross sections of peridotites recovered at Hole 651A.

\begin{tabular}{|c|c|c|c|}
\hline \multicolumn{4}{|c|}{$\begin{array}{l}\text { magnetic orientation of } \\
\text { ODP Site } 651 \text { peridotites. } \\
\text { Core and section number } \\
\text { and depth }(\text { in } \mathrm{cm}) \text { in the core } \\
\text { are indicated. } e=\text { angle be- } \\
\text { tween magnetic North and } \\
\text { the normal of cutting plane; } \\
I=\text { Inclination. }\end{array}$} \\
\hline Samples & & e & 1 \\
\hline $57-1$ & $36-38$ & 209 & 55 \\
\hline $57-1$ & $66-68$ & 75 & \\
\hline $57-1$ & $101-102$ & 69 & 57 \\
\hline $57-2$ & $13-15$ & 214 & 62 \\
\hline $57-2$ & & & \\
\hline $57-2$ & $125-127$ & 151 & 40 \\
\hline
\end{tabular}

ing chlorites, talc, and occasionally carbonates and quartz. Thus, four distinct mineral assemblages make up the Site 651 peridotites: (1) relict primary mineral assemblage; (2) high-temperature metamorphic assemblage; (3) intermediate temperature metamorphic assemblage; (4) low-temperature metamorphic assemblage.

\section{Relict Primary Mineral Assemblage}

The primary assemblage consists of olivine, orthopyroxene, and spinel. Olivine occurs as relict grains with undulating extinction scattered within the serpentine matrix. In some samples smaller $(<1 \mathrm{~mm})$ crystals are present, which are probably the result of recrystallization. Olivine ranges in composition from $89.8 \%$ to $91.5 \%$ Fo (Table 2 ). Ca content is very low $(<0.1 \%$ ) while the $\mathrm{Ni}$ content $(0.33 \%-0.43 \%)$ falls within the range of composition of upper mantle peridotites.

Orthopyroxene is commonly pseudomorphed by bastite. The original crystals are medium size (up to $0.5 \mathrm{~cm}$ ) porphyroclasts showing evidence of having been subjected to tectonic stress. 
Table 2. Electron probe analyses of olivine and orthopyroxene from ODP Site 651 peridotites. Each analysis represents average of several points.

\begin{tabular}{|c|c|c|c|c|c|c|c|c|c|c|}
\hline & \multicolumn{6}{|c|}{ Olivines } & \multicolumn{4}{|c|}{ Orthopyroxenes } \\
\hline & $\begin{array}{l}56 \mathrm{R}-1 \\
40-44\end{array}$ & $\begin{array}{l}57 R-2 \\
90-100\end{array}$ & $\begin{array}{c}57 \mathrm{R}-2 \\
126-131\end{array}$ & $\begin{array}{l}57 R-3 \\
13-15\end{array}$ & $\begin{array}{l}58 \mathrm{R}-1 \\
10-13\end{array}$ & $\begin{array}{l}58 \mathrm{R}-1 \\
30-32\end{array}$ & $\begin{array}{l}56 R-1 \\
40-44\end{array}$ & $\begin{array}{c}57 \mathrm{R}-2 \\
126-131\end{array}$ & $\begin{array}{l}58 \mathrm{R}-1 \\
10-13\end{array}$ & $\begin{array}{c}58 R-4 \\
100-102\end{array}$ \\
\hline $\mathrm{SiO}_{2}$ & 40.93 & 40.57 & 41.78 & 41.28 & 41.84 & 41.12 & 56.96 & 56.78 & 57.68 & 56.36 \\
\hline $\mathrm{TiO}_{2}^{2}$ & - & - & 0.01 & - & 0.00 & - & 0.23 & 0.08 & 0.02 & 0.01 \\
\hline $\mathrm{Al}_{2} \mathrm{O}_{3}$ & 0.01 & 0.01 & 0.01 & 0.01 & 0.03 & 0.02 & 7.96 & 2.55 & 0.58 & 2.92 \\
\hline $\mathrm{Cr}_{2} \mathrm{O}_{3}$ & - & - & - & - & - & - & - & - & - & 0.78 \\
\hline $\mathrm{FeO}$ & 9.34 & 10.01 & 9.34 & 8.10 & 8.83 & 8.44 & 6.26 & 6.01 & 6.28 & 5.26 \\
\hline $\mathrm{MnO}$ & 0.08 & 0.18 & 0.11 & 0.07 & 0.13 & 0.12 & 0.14 & 0.11 & 0.12 & 0.13 \\
\hline $\mathrm{MgO}$ & 48.73 & 49.59 & 49.69 & 50.73 & 49.08 & 50.44 & 34.03 & 33.48 & 35.18 & 33.11 \\
\hline $\mathrm{NiO}$ & 0.33 & - & - & - & - & 0.40 & - & - & - & - \\
\hline $\mathrm{CaO}$ & 0.01 & 0.04 & 0.02 & 0.00 & 0.00 & 0.03 & 0.59 & 0.61 & 0.17 & 1.34 \\
\hline $\mathrm{Na}_{2} \mathrm{O}$ & - & - & - & - & - & - & 0.02 & 0.08 & 0.05 & 0.01 \\
\hline Total & $\overline{99.44}$ & $\overline{100.40}$ & $\overline{100.90}$ & $\overline{100.19}$ & $\overline{100.16}$ & $\overline{100.57}$ & $\overline{100.16}$ & $\overline{99.73}$ & $\overline{100.10}$ & $\overline{99.92}$ \\
\hline \multicolumn{11}{|l|}{$(\%)$} \\
\hline Fo & 89.9 & 89.7 & 90.36 & 91.7 & 90.71 & 91.0 & & & & \\
\hline Wo & & & & & & & 1.1 & 1.2 & 1.2 & 2.6 \\
\hline En & & & & & & & 89.5 & 89.6 & 89.6 & 89.2 \\
\hline Fs & & & & & & & 9.3 & 9.2 & 9.2 & 8.2 \\
\hline
\end{tabular}

The composition ranges from Wo 0.3 to 2.6 , En 90.4 to 89.2 , and Fs 9.3 to 8.2 , with very low $(0.6 \%)$ to moderate $(2.92 \%)$ $\mathrm{Al}_{2} \mathrm{O}_{3}$ content (Table 2).

Spinel is the most abundant relict phase. It is generally in the form of large, holly-leaf-shaped brown crystals, often showing an opaque rim. Some spinels occur as tiny rounded grains, that are relicts left after larger spinel crystals have been replaced by chlorite. Spinel from Site 651 peridotites show $\mathrm{Cr} /(\mathrm{Cr}+\mathrm{Al})$ ranging from 0.4 to 0.8 (Table 3), and relatively high $\mathrm{Fe}^{3+}$ content. $\mathrm{TiO}_{2}$ content is variable, ranging from $0.03 \%$ to $0.57 \%$, and does not correlate with $\mathrm{Cr} /(\mathrm{Cr}+\mathrm{Al})$ ratio (Fig. 6). According to Dick and Bullen (1984) the Ti content of spinel may increase in a peridotite which has been contaminated by a melt. However, no clear evidence of melt impregnation has been observed in the samples, though in one or two samples a finegrained aggregate rim of micaceous phases around spinel might have originally been plagioclase. In a spinel $\mathrm{Cr} /(\mathrm{Cr}+\mathrm{Al})$ vs. $\mathrm{Mg} /\left(\mathrm{Mg}+\mathrm{Fe}^{2+}\right)$ diagram, the Site 651 peridotites fall in a field characterized by relatively high $\mathrm{Cr} /(\mathrm{Cr}+\mathrm{Al})$ and high $\mathrm{Fe}$ content (Fig. 7).

\section{High-Temperature Metamorphic Assemblage}

Amphiboles, in clusters or as isolated crystals, have been found in several samples. They appear as colorless, prismatic crystals, generally strained and tectonized, ranging in composition from tschermakitic hornblende through $\mathrm{Mg}$-hornblende to tremolite (Table 4). The formation of these amphiboles clearly preceded both the metamorphic event which gave rise to the talc-chlorite assemblage, and the low-temperature serpentinization. The possibility that these amphiboles derive from hightemperature hydrothermal alteration of clinopyroxene (Kimball, 1988) has been explored. However, we detected no traces of relict clinopyroxene. Experimental work by Jenkins (1981) has shown that the association olivine-orthopyroxene-amphibolechlorite is stable in the $700^{\circ}-869^{\circ} \mathrm{C}$ temperature range within pressures corresponding to the spinel lherzolite stability field. For ultramafic compositions extremely depleted in $\mathrm{Na}$, the composition of the amphibole that coexists with an aluminous phase within this P-T range is restricted to the tremolite- $\mathrm{Mg}$ hornblende range (Jasmond and Schaffer, 1972; Jenkins, 1981; 1983). This association may represent an episode of hydrous metasomatism or metamorphism which affected the primary assemblage at relatively high temperature $\left(>700^{\circ} \mathrm{C}\right.$, i.e., the highest temperature for stability of talc), before the peridotite body was tectonized, i.e., in the upper mantle. The heterogeneous distribution of amphibole in the peridotite suggests that the reactions which produced them took place in discrete zones (veins, etc.) within the rock.

Table 3. Electron probe analyses of olivine and orthopyroxene from ODP Site 651 peridotites. Each analysis represents average of several points.

\begin{tabular}{|c|c|c|c|c|c|c|c|c|c|c|c|c|c|c|c|}
\hline & $\begin{array}{c}50 \mathrm{R}-1 \\
3-5\end{array}$ & $\begin{array}{c}56 \mathrm{R}-1 \\
26-28\end{array}$ & $\begin{array}{l}56 \text { R-1 } \\
40-44\end{array}$ & $\begin{array}{c}56 \text { R-1 } \\
104-111\end{array}$ & $\begin{array}{c}56 \mathrm{R}-1 \\
124-128\end{array}$ & $\begin{array}{l}57 \text { R-1 } \\
13-15\end{array}$ & $\begin{array}{l}57 \text { R-1 } \\
85-88\end{array}$ & $\begin{array}{l}57 \text { R-2 } \\
90-100\end{array}$ & $\begin{array}{c}57 \text { R-2 } \\
126-131\end{array}$ & $\begin{array}{l}57 \text { R-3 } \\
13-15\end{array}$ & $\begin{array}{l}58 \text { R-1 } \\
10-13\end{array}$ & $\begin{array}{l}58 \mathrm{R}-1 \\
30-32\end{array}$ & $\begin{array}{c}58 \text { R-2 } \\
139-140\end{array}$ & $\begin{array}{c}58 \mathrm{R}-4 \\
100-102\end{array}$ & $\begin{array}{c}58 \mathrm{R}-4 \\
145-149\end{array}$ \\
\hline $\mathrm{Al}_{2} \mathrm{O}_{3}$ & 27.28 & 27.21 & 30.14 & 27.66 & 25.87 & 28.05 & 7.72 & 26.11 & 32.37 & 23.67 & 17.69 & 23.01 & 31.44 & 30.78 & 33.54 \\
\hline $\mathrm{Cr}_{2} \mathrm{O}_{3}$ & 37.22 & 39.89 & 37.73 & 38.45 & 39.60 & 39.74 & 43.70 & 40.09 & 35.27 & 42.30 & 47.07 & 42.11 & 36.42 & 36.48 & 34.59 \\
\hline $\mathrm{Fe}_{2} \mathrm{O}_{3}$ & 4.49 & 3.92 & 1.00 & 3.03 & 3.39 & 3.15 & 16.17 & 3.37 & 2.32 & 3.88 & 5.38 & 5.20 & 2.54 & 2.45 & 2.60 \\
\hline $\mathrm{FeO}$ & 22.39 & 15.15 & 21.17 & 19.46 & 19.91 & 17.11 & 28.70 & 19.13 & 15.96 & 19.79 & 21.13 & 20.66 & 17.41 & 18.25 & 17.28 \\
\hline $\mathrm{MgO}$ & 9.37 & 14.26 & 10.47 & 11.55 & 10.95 & 12.89 & 2.88 & 11.38 & 14.06 & 10.69 & 9.08 & 10.05 & 13.00 & 12.38 & 13.43 \\
\hline $\mathrm{TiO}_{2}$ & 0.10 & 0.23 & 0.17 & 0.57 & 0.53 & 0.07 & 0.27 & 0.31 & 0.27 & 0.24 & 0.11 & 0.07 & 0.03 & 0.15 & 0.04 \\
\hline Total & $\overline{100.95}$ & $\overline{101.16}$ & $\overline{100.70}$ & $\overline{100.72}$ & $\overline{100.25}$ & $\overline{101.01}$ & $\overline{99.44}$ & $\overline{100.39}$ & $\overline{100.25}$ & $\overline{100.57}$ & $\overline{100.46}$ & $\overline{101.10}$ & $\overline{100.84}$ & $\overline{100.49}$ & $\overline{101.48}$ \\
\hline & \multirow{2}{*}{47.7} & \multirow{2}{*}{49.2} & \multirow{2}{*}{45.6} & \multirow{2}{*}{48.1} & \multirow{2}{*}{50.7} & \multirow{2}{*}{48.7} & \multirow{2}{*}{79.7} & \multirow{2}{*}{50.8} & \multirow{2}{*}{42.2} & \multirow{2}{*}{54.5} & \multirow{2}{*}{64.1} & \multirow{2}{*}{55.2} & \multirow{2}{*}{43.7} & \multirow{2}{*}{45.8} & \multirow{2}{*}{40.9} \\
\hline$\overline{\mathrm{Cr}+\mathrm{Al}} \times 100$ & & & & & & & & & & & & & & & \\
\hline $\mathrm{Mg}$ & \multirow{2}{*}{42.7} & \multirow{2}{*}{62.6} & \multirow{2}{*}{46.2} & \multirow{2}{*}{51.4} & \multirow{2}{*}{49.6} & \multirow{2}{*}{57.3} & \multirow{2}{*}{15.2} & \multirow{2}{*}{51.4} & \multirow{2}{*}{61.1} & \multirow{2}{*}{49.0} & \multirow{2}{*}{43.3} & \multirow{2}{*}{46.4} & \multirow{2}{*}{57.19} & \multirow{2}{*}{54.5} & \multirow{2}{*}{58.1} \\
\hline$\overline{\mathrm{Fe}^{2+}+\mathrm{Mg}} \times 100$ & & & & & & & & & & & & & & & \\
\hline
\end{tabular}




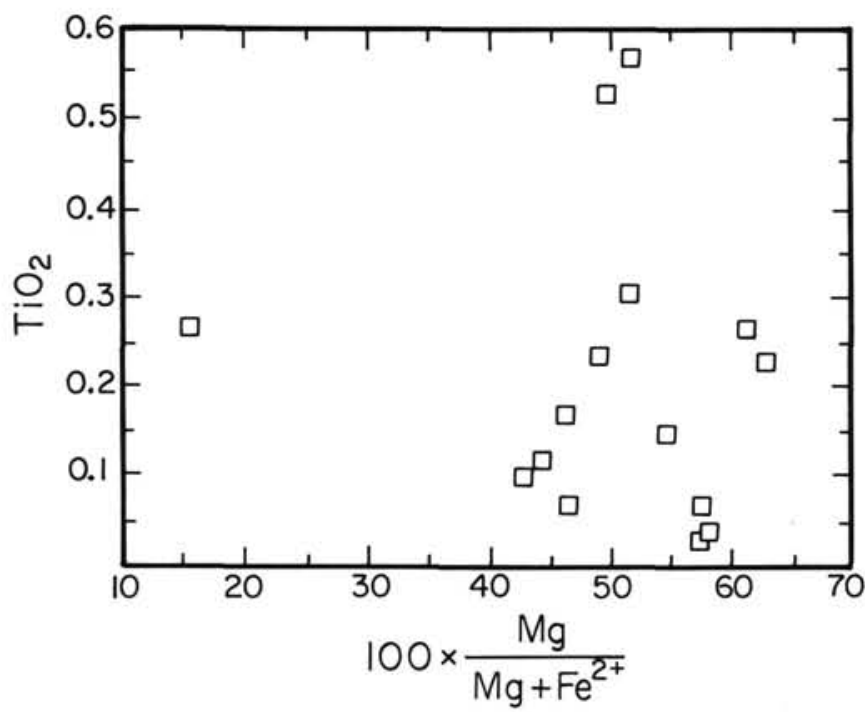

Figure 6. $\mathrm{TiO}_{2}$ vs. $100 \mathrm{Mg} /\left(\mathrm{Mg}+\mathrm{Fe}^{2+}\right)$ in spinels from Site 651 peridotites.

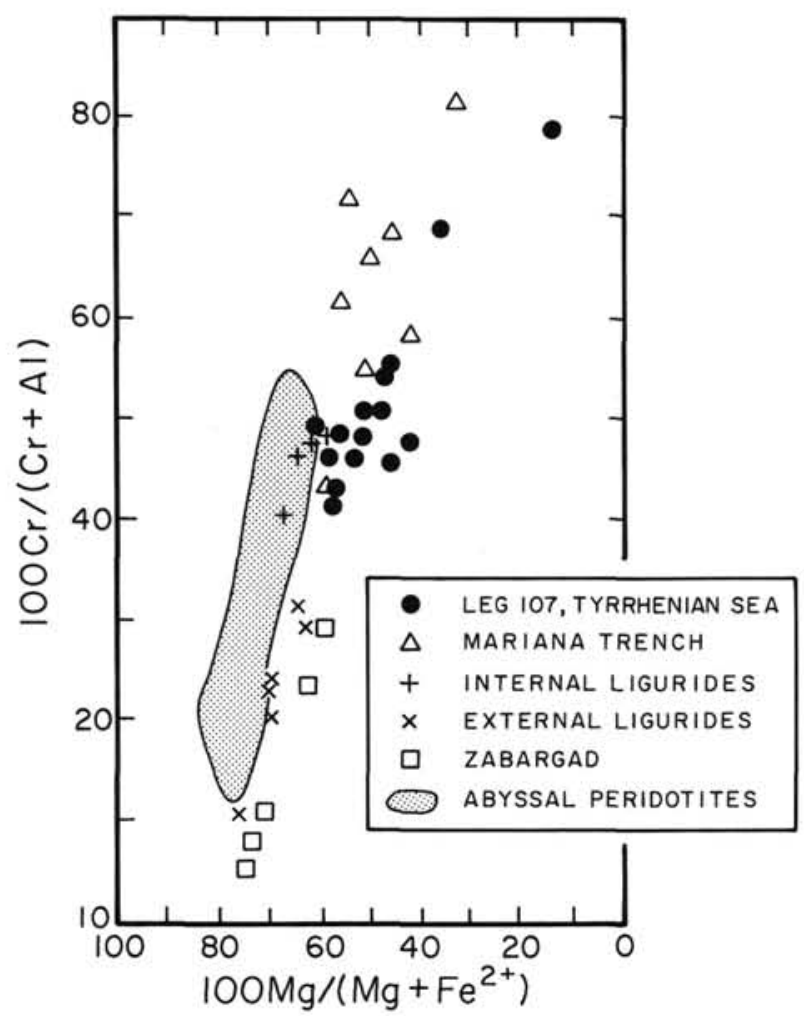

Figure 7. Spinel $100 \mathrm{Cr} /(\mathrm{Cr}+\mathrm{Al})$ vs. $100 \mathrm{Mg} /\left(\mathrm{Mg}+\mathrm{Fe}^{2+}\right)$ in ODP Site 651 peridotites. Also shown are data from oceanic peridotites (Dick and Bullen, 1984; Michael and Bonatti, 1985); from Zabargad island, Red Sea (Bonatti et al., 1986); from internal and external ligurides in the Apennine ophiolites (Beccaluva et al., 1984); and from the Mariana trench (Bloomer and Hawkins, 1983).

\section{Intermediate-temperature Metamorphic Assemblage}

This assemblage occurs in patches, fibrous aggregates, and veinlets scattered in the rock, and occasionally pseudomorphs spinel and orthopyroxene crystals. A number of phases have
Table 4. Electron probe analyses of amphibole from ODP Site 651 peridotite. The analyses represent averages of several points per each sample. They range in composition from tremolite to $\mathrm{Mg}$-hornblende.

\begin{tabular}{lrrrrrrrr}
\hline & $\begin{array}{c}50 \mathrm{R}-1 \\
3-5\end{array}$ & $\begin{array}{r}50 \mathrm{R}-1 \\
32-34\end{array}$ & $\begin{array}{r}56 \mathrm{R}-1 \\
40-44\end{array}$ & $\begin{array}{c}56 \mathrm{R}-1 \\
104-111\end{array}$ & $\begin{array}{c}56 \mathrm{R}-1 \\
104-111\end{array}$ & $\begin{array}{r}56 \mathrm{R}-1 \\
124-128\end{array}$ & $\begin{array}{r}57 \mathrm{R}-3 \\
13-15\end{array}$ & $\begin{array}{r}57 \mathrm{R}-3 \\
13-1\end{array}$ \\
\hline $\mathrm{SiO}_{2}$ & 53.43 & 52.63 & 49.95 & 53.32 & 44.01 & 53.33 & 54.80 & 45.81 \\
$\mathrm{TiO}_{2}$ & 0.16 & 0.06 & 0.28 & 0.53 & 0.26 & 0.46 & 0.28 & 0.22 \\
$\mathrm{Al}_{2} \mathrm{O}_{3}$ & 3.74 & 3.27 & 8.20 & 4.18 & 12.56 & 2.85 & 3.32 & 12.93 \\
$\mathrm{Cr}_{2} \mathrm{O}_{3}$ & 0.69 & 0.84 & 0.85 & 1.13 & 0.26 & 1.49 & 1.13 & 1.26 \\
$\mathrm{FeO}$ & 2.78 & 2.52 & 3.05 & 2.77 & 4.26 & 2.40 & 2.19 & 3.47 \\
$\mathrm{MnO}$ & 0.04 & 0.04 & 0.03 & 0.02 & 0.05 & 0.04 & 0.02 & 0.05 \\
$\mathrm{MgO}$ & 22.46 & 22.52 & 20.80 & 22.03 & 20.46 & 22.49 & 22.53 & 19.01 \\
$\mathrm{CaO}$ & 12.21 & 12.67 & 12.26 & 12.53 & 11.29 & 12.91 & 12.67 & 12.13 \\
$\mathrm{Na}{ }_{2} \mathrm{O}$ & 0.53 & 0.76 & 1.42 & 0.84 & 2.06 & 0.46 & 0.61 & 2.34 \\
$\mathrm{~K}_{2} \mathrm{O}$ & 0.03 & 0.09 & - & 0.04 & 0.09 & 0.02 & 0.04 & 0.14 \\
$\mathrm{Total}$ & 96.07 & 95.40 & 96.84 & 97.39 & 95.31 & 96.45 & 97.59 & 97.35 \\
\hline
\end{tabular}

been recognized: (1) chlorite, green to colorless in thin section, highly magnesian in composition (Table 5); (2) talc (Table 5); (3) an unidentified phyllosilicate, green to colorless in thin section, with a composition intermediate between chlorite and mica. It is rich in $\mathrm{Al}$ and $\mathrm{Mg}$ and contains up to $7 \%$ alkalis (Table 5); it is probably a mixed-layer chlorite/smectite; (4) a fibrous mineral relatively poor in $\mathrm{Al}$ (Table 5). In addition to these phyllosilicates, a few samples contain (5) quartz, either in tiny crystals or in mosaic aggregates associated with the aforementioned silicates, and in veins associated with a carbonate (6) dolomite, which is found in veinlets. Opaque minerals of the chromitemagnetite series are also present in these assemblages.

This assemblage is stable from temperatures $<700^{\circ} \mathrm{C}$ (upper limit for the stability of talc) downward, and reflects metamorphism which affected the Site 651 peridotite at crustal levels in the presence of $\mathrm{H}_{2} \mathrm{O}$.

\section{Low-temperature Metamorphic Assemblage}

The latest metamorphic events undergone by Site 651 peridotites consist of hydration processes which gave rise to widespread serpentinization.

$\mathrm{X}$-ray diffraction analyses were carried out in a few powdered samples in order to determine the nature of the serpentine minerals. A list of the main reflections obtained using $\mathrm{Cu} \mathrm{K} \alpha$ radiation is given in Table 6 . Based on criteria first outlined by Whittaker and Zussman (1956), we have interpreted these X-ray diffraction data as suggesting absence or scarcity of antigorite, and prevalence of lizardite and chrysotile among the serpentine phases. Antigorite is stable at higher temperature than chrysotile and lizardite in the serpentine multisystem (Evans et al., 1976). Serpentinization of oceanic ultramafic rocks takes place gradually during ascent in the crust at increasingly low temperature (Bonatti et al., 1984). The prevalence in the Site 651 samples of low-temperature hydrated silicates suggests that the latest serpentinization events undergone by the rocks occurred under relatively low temperature, not higher than a few hundred ${ }^{\circ} \mathrm{C}$.

\section{Whole Rock Elemental Chemistry}

Table 7 gives the whole rock major element composition of some representative samples. Evaluation of whole rock elemental composition in highly serpentinized ultramafics, such as the samples under study, must take into account that significant rock/fluid chemical exchanges may take place during serpentinization. $\mathrm{Si}, \mathrm{Mg}$, and $\mathrm{Fe}$ are particularly affected by these reactions, while $\mathrm{Al}$ and $\mathrm{Ti}$ appear to be relatively unaffected (Bonatti and Hamlyn, 1981). Whole-rock $\mathrm{Al}_{2} \mathrm{O}_{3}$ (on a $\mathrm{H}_{2} \mathrm{O}$-free basis) of oceanic serpentinized peridotites correlates with the $\mathrm{Al} / \mathrm{Cr}$ ratio of relict primary spinel, suggesting that whole-rock $\mathrm{Al}_{2} \mathrm{O}_{3}$ generally reflects the primary concentration (Bonatti and Michael, 
Table 5. Electron probe analyses of metamorphic phyllosilicates from ODP Site 651 peridotite. Each analysis represents average of several points.

\begin{tabular}{|c|c|c|c|c|c|c|c|c|c|c|c|c|}
\hline & \multicolumn{3}{|c|}{ Chlorites } & \multicolumn{3}{|c|}{ Green Phyllites } & \multicolumn{4}{|c|}{ Smectites } & \multicolumn{2}{|c|}{ Talc } \\
\hline & $56 \mathrm{R}-1$ & $57 \mathrm{R}-2$ & $57 \mathrm{R}-2$ & 57R-2 & $57 \mathrm{R}-2$ & $58 \mathrm{R}-4$ & $56 \mathrm{R}-1$ & $57 \mathrm{R}-2$ & $57 \mathrm{R}-2$ & $58 \mathrm{R}-4$ & 50R-1 & $57 \mathrm{R}-2$ \\
\hline & $124-128$ & $90-100$ & $90-100$ & $90-100$ & $126-131$ & $100-102$ & $124-128$ & $90-100$ & $90-100$ & $100-102$ & $3-5$ & $90-100$ \\
\hline $\mathrm{SiO}_{2}$ & 30.20 & 26.93 & 35.32 & 37.79 & 37.60 & 36.39 & 38.12 & 37.83 & 36.55 & 39.20 & 41.75 & 57.84 \\
\hline $\mathrm{TiO}_{2}$ & 0.13 & 0.01 & 0.01 & 0.27 & 1.19 & 0.07 & 0.06 & 0.05 & 0.22 & 0.02 & $<0.01$ & 0.01 \\
\hline $\mathrm{Al}_{2} \mathrm{O}_{3}$ & 18.77 & 26.65 & 12.74 & 18.62 & 16.59 & 12.78 & 6.87 & 3.92 & 4.41 & 2.18 & 0.62 & 0.79 \\
\hline $\mathrm{Cr}_{2} \mathrm{O}_{3}$ & 0.64 & $<0.01$ & 0.45 & 0.31 & - & 0.91 & 0.10 & 0.17 & 0.80 & 0.35 & 0 & 0.03 \\
\hline $\mathrm{FeO}$ & 2.82 & 6.49 & 4.96 & 2.97 & 4.85 & 4.65 & 3.63 & 7.10 & 8.23 & 2.36 & 9.95 & 1.91 \\
\hline $\mathrm{MnO}$ & $<0.01$ & 0.46 & 0.01 & 0.04 & 0.03 & 0.01 & 0.03 & 0.07 & 0 & 0.01 & $<0.01$ & $<0.01$ \\
\hline $\mathrm{MgO}$ & 33.81 & 25.94 & 37.57 & 26.26 & 27.44 & 31.43 & 39.19 & 38.01 & 37.77 & 41.50 & 36.82 & 31.04 \\
\hline $\mathrm{CaO}$ & 0.01 & 0.47 & 0 & 0.26 & 0.00 & 0.01 & 0.02 & 0.02 & 0.01 & 0.06 & 0.10 & 0.01 \\
\hline $\mathrm{Na}_{2} \mathrm{O}$ & 0.02 & 0.04 & 0.01 & 2.06 & 1.39 & 0.09 & 0.01 & 0.01 & 0.01 & 0.03 & 0.03 & 0.23 \\
\hline $\mathrm{K}_{2} \mathrm{O}$ & $<0.01$ & 0.01 & 0.06 & 4.27 & 4.89 & 2.76 & 0.06 & 0.02 & 0.01 & 0.01 & 0.02 & $<0.01$ \\
\hline Total & 86.38 & 87.00 & 91.40 & 92.78 & $\overline{92.93}$ & 89.11 & 88.08 & 87.20 & 88.01 & 85.71 & 89.28 & 91.88 \\
\hline
\end{tabular}

Table 6. Spacings of $\mathrm{X}$-ray reflections (in Angstrom) obtained on five samples of serpentinized peridotites from Site 651 , Tyrrhenian Sea. The relative intensity of the reflections is estimated as follows: (vs) = very strong; $(\mathrm{s})=$ strong; $(\mathrm{m})$ $=$ intermediate; $(w)=$ weak; $(\mathbf{v w})=$ very weak.

\begin{tabular}{|c|c|c|c|c|}
\hline $\begin{array}{c}57-2 \\
(105-107)\end{array}$ & $\begin{array}{c}57-2 \\
(107-109)\end{array}$ & $\begin{array}{c}58-2 \\
(34-36)\end{array}$ & $\begin{array}{c}58-4 \\
(62-66)\end{array}$ & $\begin{array}{c}58-4 \\
(122-125)\end{array}$ \\
\hline (w) & - & $8.5 \quad$ (w) & - & \\
\hline 7.2 (vs) & 7.25 (vs) & 7.25 (vs) & 7.25 (vs) & 7.25 (vs) \\
\hline $4.72(w)$ & $4.74 \quad(w)$ & $4.745(\mathrm{~m})$ & $4.79(\mathrm{vw})$ & - \\
\hline 4.57 (m) & 4.575 (m) & $4.575(\mathrm{~m})$ & 4.57 (m) & $4.575(\mathrm{~m})$ \\
\hline $\begin{array}{c}3.63 \text { (vs) } \\
-\end{array}$ & 3.64 (s) & $\begin{array}{l}3.64 \text { (vs) } \\
3.548(\mathrm{vw})\end{array}$ & $\begin{array}{c}3.64 \text { (vs) } \\
-\end{array}$ & $\begin{array}{c}3.63 \text { (vs) } \\
{ }^{2}\end{array}$ \\
\hline $3.11 \quad(w)$ & $3.11 \quad(\mathrm{vw})$ & 3.11 (m) & $3.11(\mathrm{vw})$ & $3.11(w)$ \\
\hline $2.95(\mathrm{vw})$ & 2.96 & $2.95(\mathrm{vw})$ & 2.96 (vw) & 2.959 (w) \\
\hline 2.51 (w) & 2.52 (m) & $2.515(\mathrm{~m})$ & 2.51 (w) & 2.51 (w) \\
\hline $2.495(\mathrm{~s})$ & $2.495(\mathrm{~s})$ & 2.49 (s) & $2.495(\mathrm{~m})$ & 2.49 (s) \\
\hline $2.14(w)$ & $2.141(w)$ & $2.14(w)$ & $2.146(w)$ & $2.14(w)$ \\
\hline & $2.09 \quad(\mathrm{vw})$ & - & - & $2.09(\mathrm{vw})$ \\
\hline & & - & - & $1.82(\mathrm{vw})$ \\
\hline & & - & - & 1.79 (vw) \\
\hline & & - & - & $1.61(\mathrm{vw})$ \\
\hline & & $1.533(\mathrm{~m})$ & $1.534(\mathrm{~m})$ & $1.533(\mathrm{~m})$ \\
\hline & & $1.503(w)$ & $1.506(w)$ & $1.503(\mathrm{w})$ \\
\hline & & $1.482(w)$ & $1.482(\mathrm{vw})$ & $1.482(\mathrm{vw})$ \\
\hline
\end{tabular}

Table 7. Whole rock elemental composition of serpentinized peridotites from ODP Site 651, Tyrrhenian Sea.

\begin{tabular}{lrrrrr}
\hline & $\begin{array}{c}58-2 \\
(34-36)\end{array}$ & $\begin{array}{c}58-4 \\
(62-64)\end{array}$ & $\begin{array}{c}57-2 \\
(105-107)\end{array}$ & $\begin{array}{c}57-2 \\
(107-109)\end{array}$ & $\begin{array}{c}58-4 \\
(122-125)\end{array}$ \\
\hline$(\%)$ & & & & & \\
& & & & & \\
$\mathrm{SiO}_{2}$ & 44.04 & 44.69 & 44.79 & 43.20 & 43.89 \\
$\mathrm{TiO}_{2}$ & 0.03 & 0.01 & 0.01 & 0.05 & 0.01 \\
$\mathrm{Al}_{2} \mathrm{O}_{3}$ & 0.77 & 0.56 & 0.50 & 0.85 & 0.57 \\
$\mathrm{Fe}_{2} \mathrm{O}_{3}$ & 6.02 & 5.92 & 4.97 & 5.62 & 5.08 \\
$\mathrm{FeO}_{\mathrm{O} O}$ & 1.46 & 2.13 & 2.50 & 2.08 & 2.24 \\
$\mathrm{MnO}$ & 0.08 & 0.07 & 0.08 & 0.08 & 0.06 \\
$\mathrm{MgO}$ & 35.16 & 33.90 & 34.12 & 35.85 & 35.66 \\
$\mathrm{CaO}$ & 0.24 & 0.07 & 0.21 & 0.07 & 0.03 \\
$\mathrm{Na}{ }_{2} \mathrm{O}$ & 0.02 & 0.00 & 0.00 & 0.00 & 0.00 \\
$\mathrm{~K}_{2} \mathrm{O}$ & 0.01 & 0.01 & 0.01 & 0.02 & 0.01 \\
$\mathrm{H}_{2} \mathrm{O}$ & 12.16 & 12.64 & 12.78 & 12.19 & 12.45 \\
$\mathrm{Total}$ & 99.39 & 99.41 & 99.47 & 99.45 & 99.49 \\
& & & & & \\
$(\mathrm{ppm})$ & & & & & 179 \\
$\mathrm{Cr}$ & 2080 & 1740 & 2750 & 1520 & 1720 \\
$\mathrm{Ni}$ & 1800 & 2400 & 2160 & 1470 & 2180 \\
$\mathrm{Mg} *$ & 90.24 & 89.01 & 89.70 & 89.87 & 90.42 \\
\hline
\end{tabular}

1989). We have compared (Fig. 8) the whole-rock $\mathrm{Al}_{2} \mathrm{O}_{3}$ content (recalculated on a $\mathrm{H}_{2} \mathrm{O}$-free basis) of the Tyrrhenian samples to that of: (1) serpentinized peridotites from the North Apennine ophiolites, both "external" and "internal" Ligurides (Beccaluva et al., 1984); (2) peridotites from preoceanic rifts and passive margins, i.e., Zabargad Island, Red Sea (Bonatti et al., 1986) and East Atlantic Iberian margin (Evans and Girardeau, 1988);
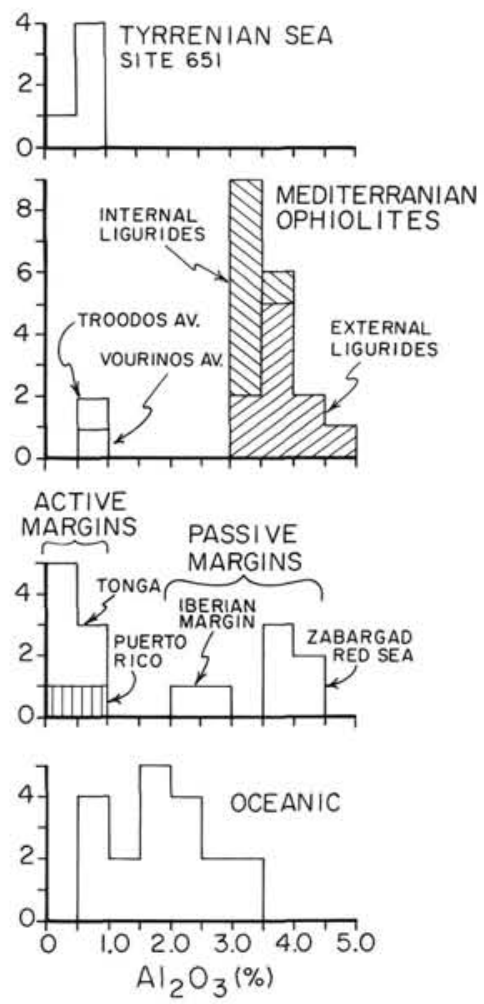

Figure 8. Whole rock $\mathrm{Al}_{2} \mathrm{O}_{3}$ concentration (recalculated on a $\mathrm{H}_{2} \mathrm{O}$-free basis) of Leg 107 Tyrrhenian Sea peridotites, compared with peridotites from North Apennine ophiolites (from Beccaluva et al., 1984); from passive margins, i.e., Zabargad in the Red Sea (from Bonatti et al., 1986) and Atlantic Iberian Margin (from Boillot et al., 1980; and Evans and Girardeau, 1988); from active, subduction margins, i.e., Puerto Rico Trench (from Bowin et al., 1968) and Tonga Trench (from Sharaskin et al., 1983); from Mediterranean, subduction-related ophiolites, i.e., Vourinos (from Moores, 1969) and Troodos (from Beccaluva et al., 1980); and from oceanic, North Atlantic peridotite averages for different regions (E. Bonatti, unpubl. data). 
(3) peridotites from the Mid Ocean Ridge system, particularly in the North Atlantic (unpubl. data); (4) peridotites from modern arc/subduction-related zones, i.e., from the Puerto Rico Trench in the Atlantic (Bowin et al., 1966); and Tonga Trench in the West Pacific (Sharaskin et al., 1983); and (5) peridotites from Mediterranean ophiolite complexes for which an arc/subduction-related origin has been inferred, i.e., Vourinos in Greece (Moores, 1969) and Troodos in Cyprus (Beccaluva et al., 1980).

The very low $\mathrm{Al}_{2} \mathrm{O}_{3}$ content of Site 651 Tyrrhenian peridotites is paralleled only by peridotites from modern arc/subductionrelated zones, i.e., Puerto Rico and Tonga trenches, and from eastern Mediterranean ophiolites with inferred arc/subductionrelated origin, i.e., Troodos and Vourinos. Similar conclusions can be reached by considering whole rock $\mathrm{TiO}_{2}$ content which primarily reflects the abundance of clino- and orthopyroxene.

\section{DISCUSSION}

\section{Island Arc/Subduction Affinity of Site 651 Mantle Peridotites}

In spite of the fact that the peridotites from Site 651 have been subjected to metasomatism, hydrothermal metamorphism, and serpentinization, some preliminary conclusions can be drawn as to the nature of the original, primary assemblage which constituted these rocks.

The original modal composition of the peridotites ranged between olivine-opx-spinel and olivine-spinel assemblages; i.e., the rocks originally ranged between harzburgite, opx-poor harzburgite, and dunite. Tectonitic textures, inferred primary modal composition, and mineral chemistry suggest that the Site 651 ultramafics were derived from the upper mantle, where they had equilibrated in the spinel peridotite P-T stability field, $>8-9$ kbar pressure.

Experimental work (Jaques and Green, 1980; Mysen and Kushiro, 1977) indicate that an increasing degree of partial melting of spinel Iherzolite in the 10-20 kbar pressure range produces changes in modal composition with rapid elimination of cpx and gradual decrease of opx. Moreover, the Fo content of olivine, $\mathrm{Mg} /(\mathrm{Mg}+\mathrm{Fe})$ of opx and $\mathrm{Cr} /(\mathrm{Cr}+\mathrm{Al})$ of spinel increase, and $\mathrm{Al}_{2} \mathrm{O}_{3}$ and $\mathrm{TiO}_{2}$ content of opx and of the whole rock decrease, with increasing degrees of partial melting. The absence of modal cpx in the primary assemblage, the high $\mathrm{Cr}$ / $(\mathrm{Cr}+\mathrm{Al})$ of spinel, and the low whole rock $\mathrm{Al}_{2} \mathrm{O}_{3}$ and $\mathrm{TiO}_{2}$ content concur in suggesting that the Site 651 peridotites have been strongly depleted of lithophile elements during one or more partial melting events.

The spinel $\mathrm{Cr} /(\mathrm{Cr}+\mathrm{Al})$ ratio of the ODP Site 651 peridotites is higher than that of modern oceanic peridotites, of peridotites from preoceanic rifts (Zabargad island in the Red Sea) and of peridotites from circum Tyrrhenian Sea Apennine ophiolites, i.e., Internal and External Ligurides (Fig. 7). The possibility that the high $\mathrm{Cr} /(\mathrm{Cr}+\mathrm{Al})$ ratio of the Site 651 spinels may be caused by high temperature alteration of these rocks has been explored. Kimball (1988) suggested that high-temperature hydrothermal alteration of peridotite with production of amphibole at the expense of clinopyroxene results also in increase of the $\mathrm{Fe}$ and $\mathrm{Cr}$ content of spinel relatively to $\mathrm{Mg}$ and $\mathrm{Al}$. We cannot exclude that some of the high spinel $\mathrm{Cr} / \mathrm{Al}$ ratios of the Site 651 rocks may have been affected by this process. However, the absence of relict clinopyroxene and the very low $\mathrm{Al}_{2} \mathrm{O}_{3}$ content of orthopyroxene and of the whole rock are consistent with the interpretation that the high $\mathrm{Cr} / \mathrm{Al}$ ratio of spinel is due primarily to the high degree of depletion of the ODP Site 651 peridotites rather than to secondary alteration.

The Tyrrhenian Sea peridotites appear to be much more refractory than peridotites from circum-Tyrrhenian ophiolites, i.e., "external" and "internal" Ligurides of the North Apen- nines, which represent presumably upper mantle in a Tethyan passive margin and small ocean basin, respectively (Decandia and Elter, 1969; Beccaluva et al., 1984). They are instead very similar in modal composition and whole rock and mineral chemistry to mantle peridotites from eastern Mediterranean ophiolites such as Troodos and Vourinos, which are strongly refractory and for which an island arc/subduction-related origin has been inferred.

The Site 651 rocks are by far more refractory than peridotites from preoceanic rifts such as Zabargad in the Red Sea (Bonatti et al., 1986) and from passive margins such as the Galicia margin in the eastern Atlantic (Evans and Girardeau, 1988).

Considering modern upper mantle peridotites, we note that the Tyrrhenian rocks are more depleted than oceanic peridotites, except for an overlap with the highly refractory North Atlantic samples from the Azores "hot spot" region (Michael and Bonatti, 1985; Dick et al., 1984). However, the Tyrrhenian Sea rocks are very similar to highly refractory peridotites from modern, subduction-related trenches, such as the Puerto Rico, Tonga. and Mariana Trenches (Bowin et al., 1966; Bloomer and Hawkins, 1983; Bonatti and Michael, 1989).

We conclude that the Site 651 mantle peridotite body was probably at some stage involved in a convergent margin, i.e., in an island arc/subduction zone geotectonic setting, where portions of upper mantle can undergo extreme degrees of depletion due to partial melting under hydrous conditions (Wyllie, 1971; Ringwood, 1975; Dick and Bullen, 1984). This conclusion is consistent with the finding that the basalts drilled at Site 651 , particularly those of Unit 3 just above the peridotites, appear to have a calk-alkaline affinity (Beccaluva et al., this volume).

\section{Metasomatism and Metamorphism of Site 651 Peridotite}

The tschermakitic and $\mathrm{Mg}$ hornblende, tremolitic amphibole, and possibly chlorite assemblage of Site 651 peridotites indicate that the peridotites were subjected to hydrous metasomatism at temperatures $>700^{\circ} \mathrm{C}$. This metasomatism preceded the tectonic deformation that affected the samples, which was probably related to the ascent of the peridotite body onto the crust. Thus, the metasomatic event probably occurred at upper mantle depths. Hydrous metasomatism in the upper mantle close to a subduction zone is consistent with the idea that a subducting slab releases $\mathrm{H}_{2} \mathrm{O}$-rich fluids, which flush through the upper mantle, and on the one hand permit hydrous-remelting of portions of mantle by lowering the peridotite solidus (Wyllie, 1971; Ringwood, 1975; Dick and Bullen, 1984), and on the other hand, provide $\mathrm{H}_{2} \mathrm{O}$-rich fluids for pervasive metasomatism.

The talc-quartz \pm chlorite assemblages suggest that the peridotites underwent $<700^{\circ} \mathrm{C}$ hydrothermal metamorphism, probably at crustal levels during ascent of the ultramafic body. The fluid responsible for this metamorphism was most likely heated seawater which was circulating at depth in the crust. It is possible that some of this hydrothermal metamorphism was in fact retrometamorphism triggered by the injection of a basaltic sill or dike, which is marked by Site 651 dolerite-albitite Unit 2 (Fig. 3).

Hydrothermal reactions involving heated seawater are probably responsible also for the intense serpentinization of Site 651 ultramafics. We note that, given the sediment thickness and the thermal gradient measured at Site 651 , a present day temperature of about $100^{\circ} \mathrm{C}$ is estimated for the basement at this site (Shipboard Scientific Party, 1987b).

\section{Mechanism of Emplacement of the Site 651 Ultramafic Body}

The structural data obtained in the Site 651 peridotites suggest that their deformation was first ductile and occurred in a 
mainly strike/slip environment, with the direction of motion being approximately from northwest/southeast to north-northwest/south-southeast. At the same time, uplift of the peridotite body is suggested by the sequence of high-temperature foliation $\rightarrow$ low-temperature foliation $\rightarrow$ brittle deformation. The latter period of brittle deformation was characterized by prevalently tensional stress. One set of faults (north-south to northeast-southwest) may represent an opening direction; a second set (northwest-southeast to east-west) may represent a transform direction. This interpretation is not in contrast with the idea that the ODP Site 651 peridotite body has been affected by an island arc/subduction system, as long as the subduction was oblique. Kinematic and geodynamic reconstructions (see Sartori et al., 1987, and references therein) indicate that the direction of subduction during the early stages of opening of the Tyrrhenian basin was north-northwest, and the strike of the plate boundary was east-southeast/west-northwest.

\section{Island Arc Migration in the Tyrrhenian Sea}

In addition to the presently active Eolian island arc in the southern Tyrrhenian (Barberi et al., 1974; Beccaluva et al., 1985), calc-alkaline convergent margin-related volcanics have been sampled in a number of localities in the Tyrrhenian, particularly on the Marsili seamount (Selli et al., 1977), in the basement of the Marsili basin at ODP Site 650 (Beccaluva et al., this volume), and on seamounts on the saddle between the Marsili and the Vavilov basins (Selli et al., 1977). Moreover, calc-alkaline volcanism is known to have occurred in the Oligocene-Miocene of Sardinia (Maciotta et al., 1978). A northwest-southeast progression of ages of this calc-alkaline volcanism is apparent, from 29-13 m.y. in Sardinia to about 3.6 m.y. at Site 651 in the Vavilov basin, to about 1.7-1.9 m.y. in the Marsili basin, and to $1.5 \mathrm{~m}$.y.-present of the Eolian arc. This age progression of calcalkaline volcanism, and the finding of arc/subduction-related upper mantle at Site 651 in the Vavilov basin are consistent with the hypothesis that the Tyrrhenian Sea opened as a result of progressive migration of island arc systems from Sardinia to the present Eolian arc, with consequent opening of back arc basins (Malinverno and Ryan, 1986; Rehault et al., 1987).

\section{ACKNOWLEDGMENTS}

This research was supported by a grant from Joint Oceanographic Institutions. We thank Vicky Costello, Mimi Schneider, and Pat Catanzaro for their help in putting together this paper. Contribution \#4535 from Lamont-Doherty Geological Observatory.

\section{REFERENCES}

Barberi, F., Innocenti, F., Ferrara, G., Keller, J. and Villari, L., 1974. Evolution of the Eolian arc volcanism (southern Tyrrhenian Sea). Earth Planet. Sci. Lett., 21:269-276.

Beccaluva, L., Piccardo G. B., and Serri, G., 1980. Petrology of northern Apennine ophiolites and comparison with other Tethyan ophiolites. In Ophiolites, Proc. Intern. Ophiolite Symposium, Cyprus, 314-331.

Beccaluva, L., Maciotta, G., Piccardo, G. B., and Zeda, O., 1984. Petrology of lherzolitic rocks from the northern Apennine ophiolites. Lithos, 17:199-316.

Beccaluva, L., Gabbianelli, G., Lucchini, F., Rossi, P. L., and Savelli, C., 1985. Petrology and $\mathrm{K} / \mathrm{Ar}$ ages of volcanics dredged from the Eolian seamounts: implications for the geodynamic evolution of the Tyrrhenian basin. Earth Planet. Sci. Lett., 74:187-208.

Bloomer, S. H., and Hawkins, J. W., 1983. Gabbroic and ultramafic rocks from Mariana Trench: an island arc ophiolite. In The Tectonic and Geologic Evolution of Southeast Asian Seas and Islands. Geophys. Monograph 27, AGU, 294-316.

Boillot, G., Grimand, S., Mauffret, A., Mougenot, D., Kornprobst, J., Mergoil-Daniel, J., and Torrent, G., 1980. Ocean-continent boundary off the Iberian Margin: a serpentinite diapir west of the Galicia Bank. Earth Planet. Sci. Lett., 48:23-34.
Bonatti, E., and Hamlyn, P. R., 1981. Oceanic ultramafic rocks. In Emiliani, C. (Ed.) The Sea, vol. 7, New York (Wiley), 241-283.

Bonatti, E., Lawrence, J. R., and Morandi, N., 1984. Serpentinization of oceanic peridotites: temperature dependence of mineralogy and boron content. Earth Planet. Sci. Lett., 70:88-94.

Bonatti, E., Ottonello, G., and Hamlyn, P. R., 1986. Peridotites from the Island of Zabargad, Red Sea: Petrology and Geochemistry. J. Geophys. Res., 91:599-631.

Bonatti, E., and Michael, P. J., 1989. Mantle peridotites from continental rifts to ocean basins to subduction zones. Earth Planet. Sci. Lett., 73:91-104.

Bowin, C. O., Nalwalk, A. J., and Hersey, J. B., 1966. Serpentinized peridotite from the North wall of the Puerto Rico Trench. Geol. Soc. Am. Bull., 77:257-270.

Decandia, F. A., and Elter, P., 1969. Riflessioni sul problema della ofioliti nell' Appennino settentrionale. Atti Soc. Toscana Sci. Natur. Mem., 75:109.

Della Vedova, B., Pellis, G., Foucher, J. P., and Rehault, J. P., 1984. Geothermal structure of the Tyrrhenian Sea. Mar. Geol., 55:271289.

Dick, H.J.B., and Bullen, T., 1984. Chromian spinel as a petrogenetic indicator in abyssal and alpine-type peridotites and associated lavas. Contrib. Mineral. Petrol., 86:54-076.

Dick, H.J.B., Fisher, R. L., and Bryan, W. B., 1984. Mineralogic variability of the uppermost mantle along mid ocean ridges. Earth Planet. Sci. Lett., 69:88-106.

Evans, B. W., Johannes, W., Oterdsom, H., and Trommsdorff, V., 1976. Stability of chrisotile and antigorite in the serpentinite multisystem. Schweiz. Mineral. Petrogr. Mitt., 56:79-93.

Franzini, M., Leoni, M., and Saitta, M., 1975. Revisione di una metodologia analitica per fluorescenza X basata sulla correzione completa degli effetti di matrice. Rend. Soc. It. Miner. Petrol., 31:365378.

Jaques, A. L., and Green, D. H., 1980. Anhydrous melting of peridotite at $0-15 \mathrm{~kb}$ pressure and the genesis of tholeitic basalts. Contrib. Mineral. Petrol., 73:283-310.

Jasmund, K., and Schaffer, R., 1972. Experimentelle Bestimmung der P-T-Stabilitatsbereiche in der Mischkristallreihe Tremolit. Tschermakit. Contrib. Mineral. Petrol., 34;101-115.

Jenkins, D. M., 1981. Experimental phase relations of hydrous peridotites modelled in the system $\mathrm{H}_{2} \mathrm{O}-\mathrm{CaO}-\mathrm{MgO}-\mathrm{Al}_{2} \mathrm{O}_{3}-\mathrm{SiO}_{2}$. Contrib. Mineral. Petrol., 77:166-176.

1983. Stability and composition of calcic amphiboles in ultramafic rocks. Contrib. Mineral. Petrol., 83:375-384.

Kastens, K., Mascle, J., et al., 1988, ODP Leg 107 in the Tyrrhenian Sea: insights into passive margin and back arc basin evolution. Geol. Soc. Am. Bull.,

Kimball, K. L., 1988. High temperature hydrothermal alteration of ultramafic cumulates from the base of the sheeted dikes in the Josephine ophiolite, NW California. J. Geophys. Res., 93:4675-4687.

Macciotta, G., Venturelli, G., and Beccaluva, L., 1978. Geochemistry of mafic cenozoic volcanic rocks from Sardinia. Bull. Volcanol., 41: 56-78.

Malinverno, A., and Ryan, W.B.F., 1986. Extension of the Tyrrhenian Sea and shortening in the Apennine as a result of arc migration driven by sinking of the lithosphere. Tectonics, 5:227-245.

Michael, P. J., and Bonatti, E., 1985. Peridotite composition from the north Atlantic: regional and tectonic variations and implications for partial melting. Earth Planet. Sci. Lett., 73:91-104.

Moores, E. M., 1969. Petrology and structure of the Vourinos ophiolitic complex of northern Greece. Geol. Soc. Am. Spec. Pap., 118 p.

Mysen, B. O., and Kushiro, I., 1977. Compositional variations of coexisting phases with degrees of melting of peridotite in the upper mantle. Am. Mineral., 62:843-856.

Rehault, J. P., Moussat, E., and Fabbri, A., 1987. Structural evolution of the Tyrrhenian back-arc basins. Mar. Geol., 74:123-150.

Rehault, J. P., Mascle, J., Fabbri, A., Moussat, E., and Thommeret, M., 1987. The Tyrrhenian Sea before Leg 107. In Kastens, K. A., Mascle, J., et al., Proc. ODP, Init. Repts., 107: College Station, TX (Ocean Drilling Program), 9-35.

Ringwood, A. E., 1975. Composition and petrology of the Earth's mantle. New York (McGraw-Hill).

Sartori, R., Mascle, G., and Amandric du Chaffaut, S., 1987. A review of circum-Tyrrhenian regional geology. In Kastens, K. A., Mascle, 
J., et al., Proc. ODP, Init. Repts., 107: College Station, TX (Ocean Drilling Program), 37-60.

Selli, R., Lucchini, F., Rossi, P. L., Savelli, C., and Del Monte, M., 1977. Dati geologici, petrochimici e radiometrici sui vulcani centro tirrenici. G. Geol., 42:221-246.

Sharaskin, A. Y., Pustchin, I. K., Zlobin, S. K., and Kolesov, G. M., 1983. Two ophiolite sequences from the basement of the northern Tonga Arc. Ofioliti, 8:411-430.

Shipboard Scientific Party, 1987a. Site 637. In Boillot, G., Winterer, E. L., et al., Proc. ODP, Init. Repts., 103: College Station, TX (Ocean Drilling Program), 123-219.

1987b. Site 651. In Kastens, K. A., Mascle, J., et al., Proc. ODP, Init. Repts., 107: College Station, TX (Ocean Drilling Program), 287-401.
Steinmetz, L., Ferrucci, F., Hirn, A., Morelli, C., and Nicolich, R., 1983. A $550 \mathrm{~km}$ long Moho traverse in the Tyrrhenian Sea from OBS recorded in waves. Geophys. Res. Lett., 10:428-431.

Whittaker, E. J., and Zussman, J., 1956. The characterization of serpentine minerals by X-ray diffraction. Mineral. Mag., 31:107-126.

Wyllie, P. S., 1971. Role of water in magma generation and initiation of diapiric uprise in the mantle. J. Geophys. Res., 76:1328-1338.

Date of initial receipt: 8 February 1988

Date of acceptance: 10 February 1989

Ms 107B-141 